\title{
Evaluating Contractors' Safety Record and Its Influence on Performance of Road Infrastructural Projects
}

\author{
James Mushori1 $^{*}$, Charles Mallans Rambo ${ }^{2}$, Charles Misiko Wafula ${ }^{2}$, Johnson Matu ${ }^{1}$ \\ ${ }^{1}$ Project Planning and Management, University of Nairobi, Nairobi City, Kenya \\ ${ }^{2}$ School of Open and Distance Learning, University of Nairobi, Nairobi City, Kenya \\ Email: ‘jameskenya23@yahoo.com, crambo@uonbi.ac.ke, charles.misiko@uonbi.ac.ke, matupec@gmail.com
}

How to cite this paper: Mushori, J., Rambo, C.M., Wafula, C.M. and Matu, J. (2021) Evaluating Contractors' Safety Record and Its Influence on Performance of Road Infrastructural Projects. World Journal of Engineering and Technology, 9, 203-228. https://doi.org/10.4236/wjet.2021.92015

Received: August 29, 2020

Accepted: March 28, 2021

Published: March 31, 2021

Copyright $\odot 2021$ by author(s) and Scientific Research Publishing Inc. This work is licensed under the Creative Commons Attribution International License (CC BY 4.0).

http://creativecommons.org/licenses/by/4.0/

\begin{abstract}
A number of studies conducted in Kenya and internationally indicated that most of the construction firms and contractors do not seem to strictly observe safety administration in construction industry, hence compromised performance at implementation stage of projects and even later in the post implementation or post-delivery stage. The study aimed to examine the influence of contractors' safety record on road performance. This is to create better understanding of how the safety record of contractors could either positively or negatively influence performance of roads during post-delivery stage. The study used both descriptive survey research design and correlation design based on a pragmatic mixed method approach. Through stratified sampling and proportionate sampling, a sample of 210 was drawn from a population of 460 comprising of registered contractors and Public Service Vehicles (PSV) drivers within Nairobi County in Kenya. Questionnaires were distributed using simple random sampling. The questionnaires returned were 153 in total representing $72.8 \%$ of all questionnaires distributed to the respondents. Data was descriptively analyzed using percentages, frequencies, means and standard deviations for measuring central tendency and variability. Inferential analysis was done by use of correlation and regression. The descriptive analysis revealed that safety policy management system, insurance policy, and adequacy of standards in addressing safety outcome are to some extent practiced and adhered to. However, compliance behavior to safety procedures is still weak and requires improvement. The null hypothesis was tested and the results obtained from a simple linear regression indicated that, $R=0.657, R^{2}$ $=0.431, \mathrm{~B}=0.359, \mathrm{t}=10.703, \mathrm{~F}(1,151)=114.558, \mathrm{p}=0.000<0.05$. This means that contractors' safety record has a strong positive and significant relationship with road performance and that $43.1 \%$ of variation in performance
\end{abstract}


is explained by safety record. This study recommends that contractors' safety record should be part, and parcel of the evaluation criteria used in selection of a suitable road contractor to ensure road performance is achieved even after construction is completed. The study is significant in that it contributes to the body of knowledge by providing empirical data on the need for safety procedures in urban road construction and beyond.

\section{Keywords}

Contractors' Safety Record, Road Performance, Road Safety, Infrastructural Projects

\section{Introduction}

Globally, the number of people killed and injured annually on the world's roads is believed to be nearly 1.25 million people and up to 50 million people respectively [1]. In the year 2010, a Decade of Action for Road Safety (2011-2020) was proclaimed by the General Assembly of the United Nations [2]. The buck, however, does not stop with the motorists and pedestrians alone but also essentially with the contractors who construct the road. At global level, commendable strides have been made by including road safety in the Sustainable Development Goals: target 3.6, which aims to halve the number of road injuries and deaths by 2020; and target 11.2, which aims to provide access to safe, affordable, accessible and sustainable transport systems for all by 2030 [2].

Safety in construction has been of so much focus during implementation stage yet ignoring the outcome in the post-delivery stage. According to Australian Transport Safety Bureau (ATSB) safety report, integrating systems for safety into the ordinary commercial operations has no indications of the ability for accident alleviation and risk management [3]. The International Finance Corporation notes that the contractors should be asked to provide details including past Environmental, Health and Safety (EHS) performance; status of Environmental and Social Management System (ESMS); number and qualifications of Environmental, Social, Health and Safety (ESHS) personnel; and last but not least is the occupational safety and health procedures and controls [4].

Documentation quantity and level of information and detail that are requested to contractors shall be commensurate to the scope of work and other specific features that the contractor is being prequalified against. This is deemed important not only to ensure safety standards are adhered to during construction phase but also to contribute to future safety expected during operational phase. In most cases, safety is normally not keenly implemented. For example, Emeasoba and Ogbuefi revealed that like in several developing economies, Nigerian statutory provisions, with capacity to ensure the assumption and operationalization of systems for safety and health management by concerns, appear to be deficient [5]. This phenomenon leads to inadequate attentiveness to critical safety 
and health matters among construction workers in Nigeria. In addition, concerns appear incapable or unwilling to offer sufficient attentiveness to safety and health management. As a result, safety and health standards, operational capacity and corporate reputation of the construction industry in Nigeria have been affected.

The continuous evaluation of project execution in regard to the design schedules, and the utilization of infrastructure, inputs, as well as services by the beneficiaries of project, is called "project monitoring". For example, Ogendi, et al. concluded that pedestrian safety ought to be of central attention in any road safety effort in Nairobi City County [6]. Accordingly, planners of urban road safety should embrace prevailing cost-effective responses to assure the pedestrian safety, including area-wide calming of traffic to control the motor vehicle speeds at $30 \mathrm{~km} / \mathrm{h}$, provision of pedestrian sidewalks, residential area traffic calming, as well as the strict operationalization of traffic rules. Additionally, Griffin and Neal posited that before engaging a contractor in construction work, the contract manager would need to be satisfied, both about the competence of the contractor to carry out the work safely, and their own competence that is, knowledge and experience to reach a sound judgment about the competence of a contractor [7]. Arrangements will need to be put in place with a main contractor for the assessment and management of any sub-contractors and the principles set out in this guidance may be used. Australian Safety Transport Bureau therefore points out that having some safety management systems in place may produce the following [3]: incidents and accidents alleviation; reduction in overt and covert costs; recognition of safety need by travelling pedestrian; reduction in insurance premiums; as well as evidence of due diligence in investigations relating to legal or regulatory safety.

Practically, properly designed as well as maintained roads are significant for the safety of roads. According to Manyara, whenever the government communicates concerns relating to Road Traffic Accidents (RTAs), roads are infrequently cited as the cause [8]. Instead, the government normally points an accusing finger at the driver, the vehicle's mechanical condition, the weather or even other set of factors. Improperly designed roads, such as steep slopes, narrow roads, uneven, as well as sharp turns or curves and poorly maintained roads with potholes and limited road signs make road users susceptible to accidents. Normally, dangerous overtaking is caused by the absence of warning signs or even centerline markers. Due to improperly constructed and maintained roads, mobility is constrained, vehicle operating costs rise unnecessarily, accident rates go up, isolation is augmented, poverty rises, health is put at risk [9]; an experience that affects urban dwellers as well. For instance, in a report released by National Transport Safety Authority (NTSA), by 2019, the number of people who died and injured on roads in Kenya were 3053 and 10,147 respectively [10]. In 2018, lower figures were recorded where 2689 died and 8569 people got injured. This is a clear indication that something imperative must be done in terms of road safety to avert these fatalities. In Nairobi alone, 373 people were killed on 
the roads.

The Nairobi City County Government (NCCG) enumerated some of the issues and challenges regarding safety and security of roads and transport system in the city. For example, there is need for capacity building of motorized drivers due to lack of security tolerance for pedestrians; this is according to the report by the said NCCG. Design of roads a lot of times does not take care of the needs of children and other vulnerable road users. People with disabilities find it difficult to negotiate the set infrastructure. No-functional street-lighting, improper and insecure location of the footbridges. Safety rules are weak as everyone tries to be alive on the road. The motor cyclists do not wear protective gears, with unsuitable bumps for the cyclists. Traffic snarl-ups occasionally make motorized drivers as well as cyclists to occupy the walkways. Due to the haphazard crossing by the pedestrians and congestion by the motorcycle taxis, confusion abounds near markets, with unmarked bikeways occasionally occupied by motorbikes [11]. This raises doubts on effectiveness of contractors' capacity evaluation in tender award, hence, the need to study the contractors' capacity and road construction infrastructural project performance in Nairobi County. The Permanent Secretary (PS) for infrastructure in Kenya noted that most of the roads within Nairobi are in the hands of careless contractors who have failed to ensure standards are met and that there was need to entrench a performance-based system of contracts to weed out contractors who do shoddy work [12]. Kahongeh noted that the four-lane Outer Ring Road "lacked footbridges, walk ways, cycle paths, lighting, signage and landscaping when it was completed in 2017. The contractor, SinoHydro Tianjin Engineer, would later erect 11 footbridges along the 13-kilometre stretch after protests from road users," [10]. It is against this backdrop that the objective of current study sought to examine how contractors' safety record could be influencing road performance in Nairobi County in Kenya when it comes to post-delivery of road infrastructural projects. The null hypothesis of the study is: contractors' safety record does not significantly influence performance of road construction infrastructural projects in Nairobi County, Kenya.

\section{Literature Review}

Safety in construction industry is vital to contribute to road performance. To adjust the safety performance of personnel, an array of activities is undertaken by safety practitioners as well as management. Some of those activities include safety communication; safety training; and safety rules and procedures. Hall and Holt posit that safety performance is employees' personal conduct through which their own safety as well as that of colleagues would be assured [13]. Two dimensions of safety therefore emerge, namely: compliance with safety safeguards, including the use of personal protective equipment (PPE), adherence to safety rules and procedures, and safety participation, including voluntary participation in such activities, including meetings for safety strategy. Many studies have demonstrated that motivation and employees' knowledge positively impacts on 
safety performance. This argument has been emphasized by Heinrich, Peterson and Roos in the below comment:

"Despite the notorious reputation of the construction industry for poor health and safety, project financiers almost never thought of it as their duty to facilitate the safety and health practices of suppliers where appropriate at the site. Therefore, upon occurrence of an incident, it could significantly impact budgetary as well as programmatic performance, despite all other parameters being in place. It was established that the procedures for the choice of suppliers were imperative for health and safety assurance, given that project sponsors never concerned themselves with the matter, as long as work was on course." [14]

The circumstances are even worse in the developing country contexts such as Iran, being an outcome of numerous dynamics, including absence of rules and regulations, mediocre inspection by government machinery, unskilled labour, poor motivation of employees, time and economic pressures, as well as lack of an integrated system for accident recording and reporting [15]. Others such as Kartam and Bouz discovered that weak systems for accident recording and reporting are a conduit for hiding the pervasive safety gaps [16].

The culture of keenness to safety issues has also been said to critically set the attitude and the significance of organizational safety [17]. Several other factors affect injury rates over and above the OSHA regulatory activities [18]. The factors determining OSHA performance can be analyzed by dissecting the process into three key elements, namely: compliance behavior, enforcement related aspects; and the sufficiency of standards to address safety output. The three components are further broken down into: safety practices and investments by the employer; on-site training of the worker on safety; integrated management of the site; the role played by the unions as well as off-site activities; technological effects; and practices related to the actual work. In addition, the negative economic as well as social outcomes of accidents are undeniable. Others such as Diugwu, Baba and Egila examined the non-material accident costs, including pain and suffering, and loss of quality of life [19]. Accordingly, they reported that the said costs comprised approximately thirty percent of direct costs of accident.

Consequently, the emergent key index has been "safety", alongside others such as the triangle of time, as well as quality, in the appraisal of construction project success; hence the undeniable need for its improvement [20] [21]. A research by Jannadi and $\mathrm{Bu}$-Khamsin focused on safety determinants in the Saudi Arabian context [22]. The research methodology was as follows: 1) literature review was undertaken for the identification of variables; 2) a list of variable dimensions and their respective indicators was developed; 3) expert interviews were then undertaken to enhance construct validity; 4) a research questionnaire based on variables and dimension indicators that were identified was developed; 5) data was the collected; 6) data analysis was undertaken; and 7) a summary of the results 
was developed [22]. The said study subjected the industrial contractors to research questionnaires and a formal interview with each contractor's official in charge of construction safety in the Saudi Arabian Eastern Province. The survey intended to collect data relating to the key determinants of industrial contractors' safety performance.

A total of 28 concerns were surveyed because they met the criterion of involvement with large-scale industrial construction activities the said province [22]. Twenty key factors as well as eighty-five minor-factors were identified as determinants of construction contractors' safety performance. The major determinants in this regard were: housekeeping and site planning; signaling and barricades; disaster and emergency preparation and planning; welfare facilities; crane and lifting equipment; signage, concrete and related framework; and cutting and welding; chemical handling. The other factors included electrical equipment; transportation handling, and disposal of risky material as well as waste; equipment for personal protection; prevention of fire; excavation, scaffolding and ladders; transportation; trenching and shoring; hand and power tools; ionization radiation, mechanical equipment; and involvement of management.

The respondents concurred on the priority listing of the foregoing safety factors [22]. The data were utilized for the identification of the key and sub-factors affecting the construction contractor's safety performance. The scale of significance attached to the major and sub-factors was arrived at based on their relative priority. Each item in the questionnaire comprised five options, via: 4 points for "very high impact"; 3 points for "high impact"; 2 points for "moderately high impact"; 1 point for "low impact"; and 0 (zero) points for "no impact". It was concluded that each of the variables under review were the most significant determinants of the safety performance of industrial construction contractor. In this regard, there was a total concurrence on three main factors, namely: engagement of management; protective equipment; and emergency/disaster preparation and planning [22]. This conclusion was driven by the reported highest impact and weights (6.0) of each of the said determinants. Hence, engagement of the management is critical to any successful safety program; this is in addition to personal protective equipment as well as emergency or disaster preparation and planning.

Some contractors have not been keen on observing regulations in the construction industry. Emeasoba and Ogbuefi conducted a study on level of awareness and effective regulation in the context of Nigerian construction industry [5]. A random distribution of questionnaires was done, without regard to the enterprise size band. The objective here was to avoid a skewed analysis through acquisition of a representative view on each item. This being an economical sampling strategy without losing the desirable attributes of probability sampling. Out of the 495 questionnaires dispatched, a total of 312 were returned comprising 271 and 41 valid and invalid questionnaires, respectively; representing 69\% response rate. An analysis of the valid responses indicated that $91 \%$ were of the 
opinion that poor safety and health impacted operations of their businesses, the balance was of the contrary opinion. Specifically, $74 \%$ reported that poor safety and health standard impacted their corporate reputation, with the balance expressing the contrary opinion.

Overall, approximately $55.9 \%$ of the respondents reported that they had no safety and health policies in place. Therefore, despite several construction contractors being probably aware of the safety and health impacts of their activities, they still had no safety and health policy in place [5]. Summarily, the research concluded that health and safety management constraints, inadequate support, asset limitations, lack of knowledge of details as well as implications, and management non-commitment impacted the safety and health strategies.

In regard to compliance measurement, it has been asserted that compliance with standards of OSHA by construction contractors is only observable by the time of actual OSHA inspection by some authorized OSHA personnel on-site [18]. The inspector identifies non-compliant on-site activities and ranks them according to the degree of severity. This inspection procedure would provide an objective measure of the degree of compliance with health and safety safeguards.

The construction industry is said to rely on the contractors' effort to significantly reduce accidents on construction sites voluntarily. A study by Feng on the effects of contractors' safety investments on safety performance identified the factors influencing the effects of safety investments on safety performance [9]. The researcher adopted a regression and correlation research design to be able to fill the gap. Data collection tools involved the use of structured interviews, archival data and questionnaires. The study targeted a total of 47 completed building projects. The main data analysis techniques were bivariate correlation and moderated regression techniques. The findings revealed that basic safety investments effect on safety performance did not hold constant considering other prevailing project conditions. In reference to Feng study, basic safety investments showed a stronger positive effect on accident prevention where a higher safety culture level was being exercised and also project hazard level had been put in place [9]. This implies that despite a contractor's keenness to more protection and safer environment, safety culture has a significant role to play in construction projects. Although this study was focused on building projects, the current study specifically focused on road construction infrastructural projects in Nairobi County in Kenya.

\subsection{Theoretical Framework}

The Domino theory of accident causation advanced by H. W. Heinrich in 1931, Domino theory of accident, attempts to present a set of axioms, otherwise called "the industrial safety axioms". The first axiom deals with cause-effect of accidents, and it stipulates that "accidents occur due to a complexity of determinants, with the accident itself being the last". Accordingly, he developed the "domino theory" model since the said sequence of factors was compared to chain of dominoes hitting and collapsing one another in series. According to 
Heinrich, Peterson and Roos, the said sequence is injury, due to: accident caused by risky act and, or physical or mechanical hazard, as a result of the person's fault, due to their ancestry and social ecosystem [14].

Five sequential antecedents from the Domino theory have been identified by Hossenian and Torghabeh, namely [23]: firstly, social ecosystem and ancestry which are among the process of knowledge acquisition at workplaces including culture, values, and attitudes; with lack of skills as well as technology for task performance, poor ecosystem and social conditions leading to human fault. Secondly, carelessness which mainly is a description of adverse personal attributes, acquired or otherwise. Such carelessness are antecedent to poor work conditions.

Thirdly, hazardous human acts, with risky conditions encompassing the faults as well as technical failures leading to accidents. Fourthly, accidents can occur as a result of risky acts leading to injuries. Finally, injury is the ultimate result of accidents. Domino's theory was further updated by Bird and Loftus in 1974 to put it in the context of management system in the manner proposed by the Domino model. The following explains the series of events in this model [23]: absence of management control system; primary causes including personal attributes, job related attributes, spontaneous causes; contact with energy as well as substance; property, human, and process loss. Therefore, Sabet, et al. argue that majority of the construction accidents have their origins from human faults as well as functional sources including facilities and equipment used in the work processes [24]. As a structural map, the domino theory has attracted considerable support and acceptance among the theories that attempt to explain the occurrence of accidents. James Reason endeavored to develop a remedy version of domino theory. The former was of the opinion that there always exists a conflation between human conduct and subsequent outcomes.

According to Sabet, et al., concerns have to hedge against the risks of accidents as a result of risky activities by the persons involved [24]. Others scholars like Mahat, et al., concur with the complexity argument of accident causation, due to the multiplicity of factors antecedent to the on-site accident itself [25]. Accordingly, there is need for an accident prevention strategy since it plays a role in the inter-relationship among the factors in question. The Domino theory model is applicable to all accidents and is a possible remedy to the management of losses. The theory is linked to contractors' safety record and performance of road construction infrastructural projects. Though the theory can be linked to accidents occurring during implementation of projects, the gap exists to further explain how accidents can occur as a result of past activities. In this case, the theory was borrowed to show the relationship of accidents happening as result of contractors' negligence in the road construction projects. This could also be referred to what Domino theory states as "hazardous human acts", which would mean that some accidents such as pedestrians being knocked down by running vehicles maybe as a result of the contractor's poor workmanship to install adequate footbridges and placing bumps in designated places. Just like the theory has been used to explain how accidents occur during the construction phase of 
the projects, it is as much as useful to explain accidents when the road is put to use after construction hence another way to measure performance of the road.

\subsection{Conceptual Framework}

The conceptual framework, designed by the authors of this study, presents the relationship between the independent and dependent variables. Thus, the independent variable is contractors' safety record whereas the dependent variable refers to performance of road construction infrastructural projects. Figure 1 illustrates this relationship in detail.

Figure 1 shows the relationship between contractors' safety record (independent variable) and performance of road construction infrastructural projects (dependent variable). The concept of contractors "safety record is explained by these indicators: safety policy management system; insurance policy; compliance behaviour; adequacy of standards in addressing the safety outcomes; and finally, certification in OSHA. Upon achievement of these aspects of contractors" safety record, it is hoped that performance of road construction infrastructural projects would be achieved in the following ways: Quality of completed road in terms of condition of drainage and water table, absence of potholes; Mobility and speed delays, congestion, average speed; Comfort and convenience in terms of smoothness and roughness of the road; Road User benefits in terms of cost reduction, travel time reduction, vehicle operating cost reduction; and, Safety properly constructed footbridges, pedestrian walkways, cycling lanes, road properly marked, adequate road signs, bus stops.

\section{Methodology}

The study embodied a pragmatic mixed method approach by employing descriptive survey research design and correlation design. Mixed method approach refers to the use of both quantitative and qualitative methodologies [26]. The target population comprised of road contractors and public service drivers totaling to 460 from which we got a sample of 210 using Krejcie and Morgan table.

\begin{tabular}{|c|c|c|}
\hline & & $\begin{array}{l}\text { Performance of Road Construction } \\
\text { Infrastructural Projects } \\
\text { Quality of completed road in terms of condition of } \\
\text { drainage and water table, absence of potholes }\end{array}$ \\
\hline $\begin{array}{l}\text { Contractory' Safety Record } \\
\text { Safety policy management system }\end{array}$ & & $\begin{array}{l}\text { Mobility and speed-delays, congestion, average } \\
\text { speed }\end{array}$ \\
\hline Insurence policy & $\mathrm{H}_{0}$ & $\begin{array}{l}\text { Comfort and convenience in terms of smoothness } \\
\text { and roughess of the road }\end{array}$ \\
\hline $\begin{array}{l}\text { Adequacy of standards in addressing safety } \\
\text { outcomes }\end{array}$ & & $\begin{array}{l}\text { Road User benefits in terms of cost reduction, travel } \\
\text { time reduction, vehicle operating cost reduction }\end{array}$ \\
\hline Certification in OSHA & & $\begin{array}{l}\text { Safety-properly constructed footbridges, } \\
\text { pedestrian walkways, cycling lanes, road properly } \\
\text { marked, adequate road signs, bus stops }\end{array}$ \\
\hline
\end{tabular}

Figure 1. Conceptual framework of contractors' safety record and performance of road construction infrastructural projects. 
The drivers are plying Outering Road and Eastern Bypass Road in Nairobi County, Kenya. Stratified sampling was used whereby target population was categorized in strata that comprised of: 48 consulting senior engineers and a similar number of 48 managing directors in consulting engineering firms; 68 senior engineers and 68 managing directors in construction companies (as per the $\mathrm{Na}$ tional Construction Authority "NCA" records); 95 Public Service Vehicles (PSV) drivers plying Outer-Ring Road and 133 drivers plying Eastern. PSV in Kenya are also referred to as "Matatu". Using Morgan and Krejcie Table of 1970, a sample size of 210 was obtained. Thereafter, a proportionate sampling technique helped to arrive at the right sample size in each stratum. Simple random was thus finally used to determine the respondents who took part in the study during distribution of questionnaires. A pilot study was conducted to improve on the validity and reliability [27] [28]. Content validity and construct validity was preferred in this study. Reliability was tested using Cronbach's Alpha reliability coefficient. Both questionnaires and interview schedules were used to gather data with a Likert scale set. The Likert scale is the widely used variation of the summated rating scale, which means it contains statements that express the degree to which a person agrees or disagrees with a statement expressed in either favor or opposition of a view of object of interest [29]. In total, $153(72.8 \%)$ of questionnaires were returned out the total 210 that were distributed. Descriptive data was analyzed and presented in frequencies, percentages, means and standard deviation. Qualitative data gathered was analyzed thematically. Inferential statistics was performed to find out how the predictor correlated with the outcome. Simple linear regression was therefore done using Analysis of Variance (ANOVA). To be able to observe the ethical issues, a letter of authority was sought from the government of Kenya through National Commission for Science, Technology and Innovation (NACOSTI). Questionnaires were distributed to the road contractor whereas the interview schedules were given to the Public Service Vehicles (PSVs) drivers also referred to as Matatu drivers in Kenya.

\section{Results}

This section presents the results on respondents' background information, the descriptive analysis, the correlation and inferential statistics.

\subsection{Questionnaire Return Rate}

Questionnaire returned were recorded in Table 1.

Results (Table 1) show that questionnaires were administered to 210 respondents, comprising 106 contractors and 104 PSV Matatu drivers. Out of these, 153 were filled and returned, representing questionnaire return rate of $72.8 \%$. In the other studies, a response rate of $73 \%$ and $73.3 \%$ were recorded respectively, [30] and [31]. The response rate of $72.8 \%$ in the current study, therefore, met the criteria set by both [32] and [33] which is $50 \%$ and above $70 \%$ respectively. This was enough to carry out inferential analyses. 
Table 1. Questionnaire return rate.

\begin{tabular}{cccc}
\hline Category of Respondents & Sample Size & Returned & Average Return Rate (\%) \\
\hline Contractors & 106 & 82 & 77.36 \\
PSVs Drivers & 104 & 71 & 68.27 \\
Total & 210 & 153 & 72.815 \\
\hline
\end{tabular}

\subsection{Demographic Information of the Respondents}

Background information about the respondents was gathered in terms of gender, age, level of education and experience.

\subsubsection{Contractors' Demographic Information}

This section presents demographic profiles for contractors (Table 2).

The demographic information of contractors (Table 2) show that majority were male contractors followed by female counterparts represented by $62(75.6 \%)$ and $20(24.4 \%)$ respectively. In terms of age, the results demonstrate that road construction is mainly run by mature citizens. The fewer number of youth in the industry could be due to lack of capacity, for example, financial and machinery aspects, to undertake large scale projects. Majority of the contractors $73(89.0 \%)$ are well educated and capable providing good road infrastructure. In respect to status of the contractors in construction firms, 15 (18.3\%) were managing directors, 22 (26.8\%) directors, 13 (15.9\%) managers, 20 (24.4\%) senior staff and $12(14.6 \%)$ supervisors. The study showed that most contractors possess minimum 6 years of work experience to over 21 years. It was found that most construction firms' have operated for over 11 years compared to firms that have operated $6-10$ years $(2.4 \%)$. The results show that majority of contractors $60(73.2 \%)$ had participated in construction of national roads while the remaining $22(26.8 \%)$ have experience in constructing international roads. Hence, a good number of contractors have a better idea of what is ailing performance of roads locally.

\subsubsection{PSVs Divers' Demographic Information}

This section presents demographic information of the respondents, specifically drivers plying Outer ring road and Eastern Bypass (Table 3).

The drivers demographic profile results (Table 3 ) indicate that majority of the drivers are males 69 (97.2\%) followed by $2(2.8 \%)$ of their female counterparts. Age-wise, all drivers have met the age requirement as stipulated by the law whereby it was found that $70.4 \%$ were above 31 years while the rest 21 (29.6\%) were between 21 and 30. The study revealed that majority of drivers possess some form of tertiary education whereby, 34 (47.9\%) had college certificates, 25 (35.2\%) college diplomas, 3 (4.2\%) Bachelor's degree and only a few of the drivers nine (12.7\%) had sat for Kenya Certificate of Secondary Education (KCSE). Moreover, drivers had over 6 years of work experience in public service transport hence all could provide quality responses to the questionnaire due to vast experience on how they perceive road performance. Table 3 also shows that 
Table 2. Contractors' demographic profile.

\begin{tabular}{|c|c|c|c|c|c|}
\hline $\begin{array}{l}\text { Categories of } \\
\text { Demographics }\end{array}$ & Values & Frequency & Percent & $\begin{array}{c}\text { Valid } \\
\text { Percent }\end{array}$ & $\begin{array}{c}\text { Cumulative } \\
\text { Percent }\end{array}$ \\
\hline \multirow{3}{*}{ Gender } & Male & 62 & 75.6 & 75.6 & 75.6 \\
\hline & Female & 20 & 24.4 & 24.4 & 100.0 \\
\hline & Total & 82 & 100 & 100 & \\
\hline \multirow{6}{*}{ Age } & $21-30$ years & 6 & 7.3 & 7.3 & 7.3 \\
\hline & $31-40$ years & 19 & 23.2 & 23.2 & 30.5 \\
\hline & $41-50$ years & 25 & 30.5 & 30.5 & 61.0 \\
\hline & $51-60$ years & 22 & 26.8 & 26.8 & 87.8 \\
\hline & 61 and above years & 10 & 12.2 & 12.2 & 100 \\
\hline & Total & 82 & 100 & 100 & \\
\hline \multirow{4}{*}{$\begin{array}{l}\text { Highest Level } \\
\text { of Education }\end{array}$} & College Diploma & 9 & 11.0 & 11.0 & 11.0 \\
\hline & Bachelor’s Degree & 46 & 56.1 & 56.1 & 67.1 \\
\hline & Master's Degree & 27 & 32.9 & 32.9 & 100 \\
\hline & Total & 82 & 100 & 100 & \\
\hline \multirow{6}{*}{$\begin{array}{c}\text { Status in } \\
\text { Organization }\end{array}$} & Managing Director & 15 & 18.3 & 18.3 & 18.3 \\
\hline & Director & 22 & 26.8 & 26.8 & 45.1 \\
\hline & Manager & 13 & 15.9 & 15.9 & 61.0 \\
\hline & Senior Staff & 20 & 24.4 & 24.4 & 85.4 \\
\hline & Supervisor & 12 & 14.6 & 14.6 & 100.0 \\
\hline & Total & 82 & 100 & 100 & \\
\hline \multirow{5}{*}{$\begin{array}{l}\text { Years of Work } \\
\text { Experience }\end{array}$} & $6-10$ years & 20 & 24.4 & 24.4 & 24.4 \\
\hline & $11-15$ years & 17 & 20.7 & 20.7 & 45.1 \\
\hline & $16-20$ years & 11 & 13.4 & 13.4 & \\
\hline & 21 and above Years & 34 & 41.5 & 41.5 & 58.5 \\
\hline & Total & 82 & 100 & 100 & 100 \\
\hline \multirow{5}{*}{$\begin{array}{c}\text { Years of Operation } \\
\text { in Road } \\
\text { Construction }\end{array}$} & $6-10$ years & 2 & 2.4 & 2.4 & 2.4 \\
\hline & $11-15$ years & 18 & 22.0 & 22.0 & 24.4 \\
\hline & $16-20$ years & 15 & 18.3 & 18.3 & 42.7 \\
\hline & 21 and above Years & 47 & 57.3 & 57.3 & 100 \\
\hline & Total & 82 & 100 & 100 & \\
\hline \multirow{3}{*}{$\begin{array}{l}\text { Category of } \\
\text { Road Involved } \\
\text { in Construction }\end{array}$} & National & 60 & 73.2 & 73.2 & 73.2 \\
\hline & International & 22 & 26.8 & 26.8 & 100.0 \\
\hline & Total & 82 & 100 & 100 & \\
\hline
\end{tabular}


Table 3. PSV drivers' demographic profile.

\begin{tabular}{|c|c|c|c|c|c|}
\hline $\begin{array}{c}\text { Categories of } \\
\text { Demographics }\end{array}$ & Values & Frequency & Percent & $\begin{array}{c}\text { Valid } \\
\text { Percent }\end{array}$ & $\begin{array}{c}\text { Cumulative } \\
\text { Percent }\end{array}$ \\
\hline \multirow{3}{*}{ Gender } & Male & 69 & 97.2 & 97.2 & 97.2 \\
\hline & Female & 2 & 2.8 & 2.8 & 100.0 \\
\hline & Total & 71 & 100 & 100 & \\
\hline \multirow{6}{*}{ Age } & $21-30$ years & 21 & 29.6 & 29.6 & 29.6 \\
\hline & $31-40$ years & 20 & 28.2 & 28.2 & 57.7 \\
\hline & $41-50$ years & 19 & 26.8 & 26.8 & 84.5 \\
\hline & $51-60$ years & 5 & 7.0 & 7.0 & 91.5 \\
\hline & 61 and above years & 6 & 8.5 & 8.5 & 100 \\
\hline & Total & 71 & 100 & 100 & \\
\hline \multirow{5}{*}{$\begin{array}{l}\text { Highest Level } \\
\text { of Education }\end{array}$} & KCSE & 9 & 12.7 & 12.7 & 12.7 \\
\hline & College Certificate & 34 & 47.9 & 47.9 & 60.6 \\
\hline & College Diploma & 25 & 35.2 & 35.2 & 95.8 \\
\hline & Bachelor's Degree & 3 & 4.2 & 4.2 & 100 \\
\hline & Total & 71 & 100 & 100 & \\
\hline \multirow{3}{*}{$\begin{array}{c}\text { Status in } \\
\text { Organization }\end{array}$} & Driver & 49 & 69.0 & 69.0 & 69.0 \\
\hline & Driver/Conductor & 22 & 31.0 & 31.0 & 100.0 \\
\hline & Total & 71 & 100 & 100 & \\
\hline \multirow{5}{*}{$\begin{array}{l}\text { Years of Work } \\
\text { Experience }\end{array}$} & $6-10$ years & 20 & 24.4 & 24.4 & 24.4 \\
\hline & $11-15$ years & 17 & 20.7 & 20.7 & 45.1 \\
\hline & $16-20$ years & 11 & 13.4 & 13.4 & 58.5 \\
\hline & 21 and above Years & 34 & 41.5 & 41.5 & 100 \\
\hline & Total & 71 & 100 & 100 & \\
\hline \multirow{6}{*}{$\begin{array}{c}\text { PSV Years of } \\
\text { Operation in } \\
\text { Transport Industry }\end{array}$} & 5 and below years & 5 & 7.0 & 7.0 & 7.0 \\
\hline & $6-10$ years & 28 & 39.4 & 39.4 & 46.5 \\
\hline & $11-15$ years & 8 & 11.3 & 11.3 & 57.7 \\
\hline & $16-20$ years & 11 & 15.5 & 15.5 & 73.2 \\
\hline & 21 and above Years & 34 & 26.8 & 26.8 & \\
\hline & Total & 71 & 100 & 100 & 100 \\
\hline \multirow{3}{*}{$\begin{array}{c}\text { Name of the } \\
\text { Road PSV Plying }\end{array}$} & Outer Ring & 40 & 56.3 & 56.3 & 56.3 \\
\hline & Eastern Bypass & 31 & 43.7 & 43.7 & 100.0 \\
\hline & Total & 71 & 100 & 100 & \\
\hline
\end{tabular}

many of Public service vehicles (PSVs) have been driven for a longer period of time which could help us learn more about their performance as a result of the roads they are driven on in terms of depreciation and user costs generally. Finally, 40 (56.3\%) of PSV drivers indicated they use Outer ring road, while the 
rest $31(43.7 \%)$ ply Eastern Bypass road. This implies that a good number of Matatu drivers would share their opinion on the performance of these two roads that were recently constructed.

\subsection{Performance of Road Construction Infrastructural Projects}

It was deemed necessary to ascertain respondents' opinions on performance of roads. Perceptions of respondents on each of the following dimensions of performance of road construction infrastructural projects: quality of completed road in terms of condition of drainage and water table; mobility and speed - delays, congestion, average travel speed; comfort/convenience in terms of smoothness and roughness of the road; road user benefits in terms of cost reduction, travel time reduction, vehicle operating cost reduction; and road safety were each measured within the scale. The Likert scale ranged from 5-Strongly Agree (SA), 4-Agree (A), 3-Neutral (N), 2-Disagree (D), and 1-Strongly Disagree (SD). The results are in Table 4.

The means of 21 items used to generate data on performance of road construction infrastructural projects were summed up and used to compute the composite mean and standard deviation that resulted to 3.36 and 0.297 respectively (Table 4). Statements with means below the composite mean were considered not to influence road performance positively.

From Table 4, it is evident that the functionality of the current road drainage system cannot stand to provide long-term performance. It is also clear that the water table is a problem and that the drainage system is not permeable for residuals. Statistics found shows that the roads always flood whenever there are heavy rains. In terms of the safety of the roads, bumps are not provided in the right designated areas. Lastly, pedestrian walkways are not adequately provided which could be the reason these roads record high number of accidents. These results are linked to seven statements $(1,2,3,4,5,6$ and 7$)$ that continue to negatively affect the performance of the roads. There is therefore need to rectify these issues to improve on performance.

Results of interviews with 82 road construction engineers indicated that there was concurrence among them about the state of performance of road construction infrastructural projects. The interview question posed was that, "what are the challenges you have experienced as far as performance of road is concerned?" The results of the interviews were collected and analyzed thematically whereby these results were consistent with the quantitative data. The following are key responses obtained from the road construction engineers:

- Rain is the main concern; excessive rains sweep away the tarmac,

- A contractor is also limited by the variation of project design;

- Poor performing roads is a result of public interference,

- Inadequate drainage for storm water,

- Disposal of wastewater overburdens drains and un-hygienically recommended; 
Table 4. Performance of road construction infrastructural projects.

\begin{tabular}{|c|c|c|c|c|c|c|c|c|}
\hline No & Statements & $\begin{array}{l}5(\mathrm{SA}) \\
\mathrm{F}(\%)\end{array}$ & $\begin{array}{l}4(\mathrm{~A}) \\
\mathrm{F}(\%)\end{array}$ & $\begin{array}{l}3(\mathrm{~N}) \\
\mathrm{F}(\%)\end{array}$ & $\begin{array}{c}(2) \\
\text { D F (\%) }\end{array}$ & $\begin{array}{c}(1) \\
\text { SD F (\%) }\end{array}$ & Mean & SDV \\
\hline & $\begin{array}{l}\text { (a) Quality of Completed Road in terms of } \\
\text { condition of drainage and water table }\end{array}$ & & & & & & & \\
\hline 1. & $\begin{array}{l}\text { The road is built with a functional drainage systems } \\
\text { to provide long-term road performance }\end{array}$ & $\begin{array}{c}23 \\
(15.0 \%)\end{array}$ & $\begin{array}{c}32 \\
(20.9 \%)\end{array}$ & $\begin{array}{c}44 \\
(28.8 \%)\end{array}$ & $\begin{array}{c}24 \\
(15.7 \%)\end{array}$ & $\begin{array}{c}30 \\
(19.6 \%)\end{array}$ & 2.96 & 1.327 \\
\hline 2. & $\begin{array}{l}\text { The road is well constructed with water table that } \\
\text { does not permit flooding }\end{array}$ & $\begin{array}{c}0 \\
(0.0 \%)\end{array}$ & $\begin{array}{c}16 \\
(10.5 \%)\end{array}$ & $\begin{array}{c}47 \\
(30.7 \%)\end{array}$ & $\begin{array}{c}61 \\
(39.9 \%)\end{array}$ & $\begin{array}{c}29 \\
(18.9 \%)\end{array}$ & 2.33 & 0.902 \\
\hline 3. & $\begin{array}{l}\text { Road constructed with adequate drainage systems } \\
\text { depends entirely on contractor capacity to do the job }\end{array}$ & $\begin{array}{c}35 \\
(22.9 \%)\end{array}$ & $\begin{array}{c}44 \\
(28.8 \%)\end{array}$ & $\begin{array}{c}43 \\
(28.1 \%)\end{array}$ & $\begin{array}{c}30 \\
(19.6 \%)\end{array}$ & $\begin{array}{c}1 \\
(0.6 \%)\end{array}$ & 3.54 & 0.070 \\
\hline 4. & $\begin{array}{l}\text { Drainage system is operative and allows passage of } \\
\text { residual }\end{array}$ & $\begin{array}{c}5 \\
(3.2 \%)\end{array}$ & $\begin{array}{c}28 \\
(18.3 \%)\end{array}$ & $\begin{array}{c}27 \\
(17.7 \%)\end{array}$ & $\begin{array}{c}60 \\
(39.2 \%)\end{array}$ & $\begin{array}{c}33 \\
(21.6 \%)\end{array}$ & 2.42 & 1.116 \\
\hline 5. & Proper workmanship is evidenced by lack of potholes & $\begin{array}{c}42 \\
(27.5 \%)\end{array}$ & $\begin{array}{c}75 \\
(49.0 \%)\end{array}$ & $\begin{array}{c}33 \\
(21.6 \%)\end{array}$ & $\begin{array}{c}3 \\
(1.9 \%)\end{array}$ & $\begin{array}{c}0 \\
(0.0 \%)\end{array}$ & 4.02 & 0.756 \\
\hline
\end{tabular}

(b) Mobility and Speed - delays, congestion, average travel speed

\begin{tabular}{|c|c|c|c|c|c|c|c|c|}
\hline 6. & Congestion has significantly reduced & $\begin{array}{c}30 \\
(19.6 \%)\end{array}$ & $\begin{array}{c}117 \\
(76.5 \%)\end{array}$ & $\begin{array}{c}6 \\
(3.9 \%)\end{array}$ & $\begin{array}{c}0 \\
(0.0 \%)\end{array}$ & $\begin{array}{c}0 \\
(0.0 \%)\end{array}$ & 4.16 & 0.460 \\
\hline 7. & Delays are reduced & $\begin{array}{c}25 \\
(16.3 \%)\end{array}$ & $\begin{array}{c}115 \\
(75.2 \%)\end{array}$ & $\begin{array}{c}13 \\
(8.5 \%)\end{array}$ & $\begin{array}{c}0 \\
(0.0 \%)\end{array}$ & $\begin{array}{c}0 \\
(0.0 \%)\end{array}$ & 4.08 & 0.494 \\
\hline 8. & Average travel speed has generally improved & $\begin{array}{c}58 \\
(37.9 \%)\end{array}$ & $\begin{array}{c}74 \\
(48.4 \%)\end{array}$ & $\begin{array}{c}21 \\
(13.7 \%)\end{array}$ & $\begin{array}{c}0 \\
(0.0 \%)\end{array}$ & $\begin{array}{c}0 \\
(0.0 \%)\end{array}$ & 4.24 & 0.679 \\
\hline
\end{tabular}

\section{(c) Comfort/Convenience in terms of} smoothness and roughness of the road

\begin{tabular}{|c|c|c|c|c|c|c|c|c|}
\hline 9. & The texture of the road is good & $\begin{array}{c}67 \\
(43.8 \%)\end{array}$ & $\begin{array}{c}55 \\
(35.9 \%)\end{array}$ & $\begin{array}{c}30 \\
(19.6 \%)\end{array}$ & $\begin{array}{c}0 \\
(0.0 \%)\end{array}$ & $\begin{array}{c}1 \\
(0.7 \%)\end{array}$ & 4.22 & 0.805 \\
\hline 10. & The skid resistance of the road surface is good & $\begin{array}{c}45 \\
(29.4 \%)\end{array}$ & $\begin{array}{c}64 \\
(41.8 \%)\end{array}$ & $\begin{array}{c}33 \\
(21.6 \%)\end{array}$ & $\begin{array}{c}10 \\
(6.5 \%)\end{array}$ & $\begin{array}{c}1 \\
(0.7 \%)\end{array}$ & 3.93 & 0.911 \\
\hline 11. & $\begin{array}{l}\text { Flooding of the road is not experienced during } \\
\text { heavy downpours (rainy season) }\end{array}$ & $\begin{array}{c}6 \\
(3.9 \%)\end{array}$ & $\begin{array}{c}3 \\
(2.0 \%)\end{array}$ & $\begin{array}{c}36 \\
(23.5 \%)\end{array}$ & $\begin{array}{c}51 \\
(33.3 \%)\end{array}$ & $\begin{array}{c}57 \\
(37.3 \%)\end{array}$ & 2.09 & 1.023 \\
\hline
\end{tabular}

(d) Road User benefits in terms of cost reduction, travel time reduction, vehicle operationg cost reduction

\begin{tabular}{|c|c|c|c|c|c|c|c|c|}
\hline 12. & The vehicles take longer to depreciate & $\begin{array}{c}12 \\
(7.8 \%)\end{array}$ & $\begin{array}{c}84 \\
(54.9 \%)\end{array}$ & $\begin{array}{c}34 \\
(22.2 \%)\end{array}$ & $\begin{array}{c}3 \\
(2.0 \%)\end{array}$ & $\begin{array}{c}20 \\
(13.1 \%)\end{array}$ & 3.42 & 1.110 \\
\hline 13. & $\begin{array}{l}\text { The vehicle breakdowns on the roads has reduced } \\
\text { due to good road constructed }\end{array}$ & $\begin{array}{c}24 \\
(15.7 \%)\end{array}$ & $\begin{array}{c}85 \\
(55.6 \%)\end{array}$ & $\begin{array}{c}44 \\
(28.7 \%)\end{array}$ & $\begin{array}{c}0 \\
(0.0 \%)\end{array}$ & $\begin{array}{c}0 \\
(0.0 \%)\end{array}$ & 3.87 & 0.656 \\
\hline \multirow[t]{2}{*}{14.} & $\begin{array}{l}\text { Due to properly constructed road the road user } \\
\text { costs has tremendously reduced }\end{array}$ & $\begin{array}{c}18 \\
(11.8 \%)\end{array}$ & $\begin{array}{c}83 \\
(54.2 \%)\end{array}$ & $\begin{array}{c}16 \\
(10.5 \%)\end{array}$ & $\begin{array}{c}15 \\
(9.8 \%)\end{array}$ & $\begin{array}{c}21 \\
(13.7 \%)\end{array}$ & 3.41 & 1.227 \\
\hline & (e) Road Safety & & & & & & & \\
\hline 15. & Reported cases of accidents have reduced & $\begin{array}{c}38 \\
(24.8 \%)\end{array}$ & $\begin{array}{c}72 \\
(47.1 \%)\end{array}$ & $\begin{array}{c}28 \\
(18.3 \%)\end{array}$ & $\begin{array}{c}2 \\
(1.3 \%)\end{array}$ & $\begin{array}{c}13 \\
(8.5 \%)\end{array}$ & 3.78 & 1.100 \\
\hline 16. & Roads are having enough signage & $\begin{array}{c}9 \\
(5.9 \%)\end{array}$ & $\begin{array}{c}81 \\
(52.9 \%)\end{array}$ & $\begin{array}{c}45 \\
(29.4 \%)\end{array}$ & $\begin{array}{c}15 \\
(9.8 \%)\end{array}$ & $\begin{array}{c}3 \\
(2.0 \%)\end{array}$ & 3.51 & 0.828 \\
\hline
\end{tabular}




\section{Continued}

\begin{tabular}{|c|c|c|c|c|c|c|c|c|}
\hline 17. & Bumps are provided in the designated places & $\begin{array}{c}14 \\
(9.1 \%)\end{array}$ & $\begin{array}{c}55 \\
(35.9 \%)\end{array}$ & $\begin{array}{c}24 \\
(15.7 \%)\end{array}$ & $\begin{array}{c}57 \\
(37.3 \%)\end{array}$ & $\begin{array}{c}3 \\
(2.0 \%)\end{array}$ & 3.13 & 1.080 \\
\hline 18. & $\begin{array}{l}\text { Road users do know the meaning of most of the } \\
\text { signage language }\end{array}$ & $\begin{array}{c}54 \\
(35.3 \%)\end{array}$ & $\begin{array}{c}70 \\
(45.8 \%)\end{array}$ & $\begin{array}{c}28 \\
(18.3 \%)\end{array}$ & $\begin{array}{c}0 \\
(0.0 \%)\end{array}$ & $\begin{array}{c}1 \\
(0.6 \%)\end{array}$ & 4.15 & 0.759 \\
\hline 19. & Pedestrians' walkways adequately provided & $\begin{array}{c}16 \\
(10.5 \%)\end{array}$ & $\begin{array}{c}43 \\
(28.0 \%)\end{array}$ & $\begin{array}{c}34 \\
(22.2 \%)\end{array}$ & $\begin{array}{c}44 \\
(28.8 \%)\end{array}$ & $\begin{array}{c}16 \\
(10.5 \%)\end{array}$ & 2.99 & 1.189 \\
\hline 20. & Footbridges are sufficiently provided & $\begin{array}{c}8 \\
(5.2 \%)\end{array}$ & $\begin{array}{c}0 \\
(0.0 \%)\end{array}$ & $\begin{array}{c}32 \\
(20.9 \%)\end{array}$ & $\begin{array}{c}54 \\
(35.3 \%)\end{array}$ & $\begin{array}{c}59 \\
(38.6 \%)\end{array}$ & 2.05 & 1.035 \\
\hline 21 & $\begin{array}{l}\text { Bus stops are well and placed in the right designated } \\
\text { areas }\end{array}$ & $\begin{array}{c}8 \\
(5.2 \%)\end{array}$ & $\begin{array}{c}18 \\
(11.7 \%)\end{array}$ & $\begin{array}{c}15 \\
(9.8 \%)\end{array}$ & $\begin{array}{c}70 \\
(45.8 \%)\end{array}$ & $\begin{array}{c}42 \\
(27.5 \%)\end{array}$ & 2.22 & 1.129 \\
\hline & Composite mean and standard deviation & & & & & & 3.36 & 0.297 \\
\hline
\end{tabular}

- Poor Social life of road users mainly causing traffic congestion; there is need therefore to encourage public systems of transport than private vehicles (poor social lifestyle); encroachment by road hawkers, limit performance around road reserves; ignorance on the part of public service vehicle to fully observe road marks;

- Large volumes of personal vehicles; a trend on over relying on personal vehicles exceeding traffic designed stream density resulting to snarl-ups or congestion hence poor road performance.

Results of interviews with 71 public service vehicles (PSVs) drivers indicated that there was concurrence among them about the state of performance of road construction infrastructural projects. The interview question posed was that, "what are the challenges you have experienced as far as performance of road is concerned?" The results of the interviews were, therefore, consistent with the quantitative data. The following are key responses obtained from the PSVs drivers:

- Accidents occurring on roads on daily basis,

- Flooding during heavy rain seasons,

- Road safety signs are lacking and hence some accidents happen;

- Bus stops are not adequate and therefore drivers are forced to pick and drop passengers in the middle of the road which is a safety concerns to both the clients and drivers;

- There are no footbridges in common areas that would enable pedestrians or public cross the road. For example, at Mutindwa market, pedestrians are a cause of traffic congestion and this works against the mobility of vehicles,

- There is a drainage problem.

\subsection{Contractors' Safety Record and Performance of Road Construction Infrastructural Project}

Safety in construction is a key aspect that needs to be factored when measuring road performance. The study therefore examined the influence contractors' safety record on performance of roads. The respondents were asked to, in a scale of $1-5$; score various statements relating to specific indicators of safety record of 
a contractor. The dimensions of safety record under which the indicators were drawn were safety policy management system; insurance policy; compliance behavior; adequacy of standards in addressing safety outcome; and certification in OSHA. The Likert scale ranged from 5-Strongly Agree (SA), 4-Agree (A), 3-Neutral (N), 2-Disagree (D), and 1-Strongly Disagree (SD). The results were as shown in Table 5.

Table 5. Contractors' safety record and performance of road construction infrastructural projects.

\begin{tabular}{|c|c|c|c|c|c|c|c|c|}
\hline No. & Statements & $\begin{array}{c}5 \text { (SA) F } \\
(\%)\end{array}$ & $\begin{array}{c}4(\mathrm{~A}) \mathrm{F} \\
(\%)\end{array}$ & $\begin{array}{c}3(\mathrm{~N}) \mathrm{F} \\
(\%)\end{array}$ & $\begin{array}{l}2(\mathrm{SD}) \mathrm{F} \\
(\%)\end{array}$ & $\begin{array}{c}1(\mathrm{D}) \mathrm{F} \\
(\%)\end{array}$ & Mean & SDV \\
\hline & \multicolumn{8}{|l|}{ (a) Safety Policy Management system } \\
\hline 1. & $\begin{array}{l}\text { Most contractors have a safety policy management } \\
\text { system }\end{array}$ & $\begin{array}{c}7 \\
(4.6 \%)\end{array}$ & $\begin{array}{c}76 \\
(49.7 \%)\end{array}$ & $\begin{array}{c}50 \\
(32.7 \%)\end{array}$ & $\begin{array}{c}20 \\
(13.0 \%)\end{array}$ & $\begin{array}{c}0 \\
(0.0 \%)\end{array}$ & 3.33 & 1.050 \\
\hline 2. & $\begin{array}{l}\text { Safety for most contractors is a priority to road } \\
\text { performance after completion }\end{array}$ & $\begin{array}{c}19 \\
(12.4 \%)\end{array}$ & $\begin{array}{c}63 \\
(41.2 \%)\end{array}$ & $\begin{array}{c}60 \\
(39.2 \%)\end{array}$ & $\begin{array}{c}8 \\
(5.2 \%)\end{array}$ & $\begin{array}{c}3 \\
(2.0 \%)\end{array}$ & 3.54 & 0.925 \\
\hline 3. & $\begin{array}{l}\text { Safety is taken into account for future road } \\
\text { performance }\end{array}$ & $\begin{array}{c}23 \\
(15.0 \%)\end{array}$ & $\begin{array}{c}42 \\
(27.5 \%)\end{array}$ & $\begin{array}{c}30 \\
(19.6 \%)\end{array}$ & $\begin{array}{c}15 \\
(9.8 \%)\end{array}$ & $\begin{array}{c}43 \\
(28.1 \%)\end{array}$ & 3.10 & 1.245 \\
\hline 4. & $\begin{array}{l}\text { Road contractors find it necessary to have a policy } \\
\text { management system to ensure road performance } \\
\text { because the projects they undertake are one-time }\end{array}$ & $\begin{array}{c}24 \\
(15.7 \%)\end{array}$ & $\begin{array}{c}46 \\
(30.1 \%)\end{array}$ & $\begin{array}{c}63 \\
(41.2 \%)\end{array}$ & $\begin{array}{c}0 \\
(0.0 \%)\end{array}$ & $\begin{array}{c}20 \\
(13.0 \%)\end{array}$ & 3.48 & 0.911 \\
\hline & \multicolumn{8}{|l|}{ (b) Insurance Policy } \\
\hline 5. & $\begin{array}{l}\text { Construction personnel under insurance policy } \\
\text { can also feel obligated to provide and enforce safety } \\
\text { measures which can contribute to road performance } \\
\text { and particularly road user satisfaction }\end{array}$ & $\begin{array}{c}23 \\
(15.0 \%)\end{array}$ & $\begin{array}{c}97 \\
(63.4 \%)\end{array}$ & $\begin{array}{c}27 \\
(17.6 \%)\end{array}$ & $\begin{array}{c}0 \\
(0.0 \%)\end{array}$ & $\begin{array}{c}6 \\
(4.0 \%)\end{array}$ & 3.90 & 0.690 \\
\hline 6. & $\begin{array}{l}\text { Most construction companies do have insurance } \\
\text { policy }\end{array}$ & $\begin{array}{c}23 \\
(15.0 \%)\end{array}$ & $\begin{array}{c}29 \\
(19.0 \%)\end{array}$ & $\begin{array}{c}43 \\
(28.1 \%)\end{array}$ & $\begin{array}{c}21 \\
(13.7 \%)\end{array}$ & $\begin{array}{c}37 \\
(24.2 \%)\end{array}$ & 2.97 & 1.262 \\
\hline & \multicolumn{8}{|l|}{ (c) Compliance behaviour } \\
\hline 7. & $\begin{array}{l}\text { Contractors level of compliance to safety } \\
\text { administration is clear }\end{array}$ & $\begin{array}{c}7 \\
(4.6 \%)\end{array}$ & $\begin{array}{c}29 \\
(19.0 \%)\end{array}$ & $\begin{array}{c}65 \\
(42.5 \%)\end{array}$ & $\begin{array}{c}20 \\
(13.0 \%)\end{array}$ & $\begin{array}{c}32 \\
(20.9 \%)\end{array}$ & 2.81 & 1.037 \\
\hline 8. & Contractors fully comply to safety requirements & $\begin{array}{c}17 \\
(11.1 \%)\end{array}$ & $\begin{array}{c}42 \\
(27.5 \%)\end{array}$ & $\begin{array}{c}29 \\
(19.0 \%)\end{array}$ & $\begin{array}{c}27 \\
(17.6 \%)\end{array}$ & $\begin{array}{c}38 \\
(24.8 \%)\end{array}$ & 2.90 & 1.294 \\
\hline 9. & $\begin{array}{l}\text { The environment in which contractors operate does } \\
\text { appraise compliance to safety procedures }\end{array}$ & $\begin{array}{c}13 \\
(8.5 \%) \\
\end{array}$ & $\begin{array}{c}11 \\
(7.2 \%)\end{array}$ & $\begin{array}{c}40 \\
(26.1 \%)\end{array}$ & $\begin{array}{c}22 \\
(14.4 \%)\end{array}$ & $\begin{array}{c}67 \\
(43.8 \%) \\
\end{array}$ & 2.52 & 1.095 \\
\hline & \multicolumn{8}{|l|}{$\begin{array}{l}\text { (d) Adequacy of standards in addressing safety } \\
\text { outcome }\end{array}$} \\
\hline 10. & $\begin{array}{l}\text { Construction contractors have adequate standards } \\
\text { to address issues of road performance }\end{array}$ & $\begin{array}{c}31 \\
(20.2 \%)\end{array}$ & $\begin{array}{c}52 \\
(34.0 \%)\end{array}$ & $\begin{array}{c}56 \\
(36.6 \%)\end{array}$ & $\begin{array}{c}3 \\
(2.0 \%)\end{array}$ & $\begin{array}{c}11 \\
(7.2 \%)\end{array}$ & 3.63 & 0.951 \\
\hline 11. & $\begin{array}{l}\text { Adequate safety standards guarantee road } \\
\text { performance }\end{array}$ & $\begin{array}{c}23 \\
(15.0 \%)\end{array}$ & $\begin{array}{c}86 \\
(56.2 \%)\end{array}$ & $\begin{array}{c}29 \\
(19.0 \%)\end{array}$ & $\begin{array}{c}15 \\
(9.8 \%)\end{array}$ & $\begin{array}{c}0 \\
(0.0 \%)\end{array}$ & 3.67 & 1.058 \\
\hline 12. & $\begin{array}{l}\text { Construction safety standards are reviewed and } \\
\text { conform to international standards }\end{array}$ & $\begin{array}{c}66 \\
(43.2 \%)\end{array}$ & $\begin{array}{c}47 \\
(30.7 \%)\end{array}$ & $\begin{array}{c}36 \\
(23.5 \%)\end{array}$ & $\begin{array}{c}2 \\
(1.3 \%)\end{array}$ & $\begin{array}{c}2 \\
(1.3 \%)\end{array}$ & 4.13 & 0.908 \\
\hline & \multicolumn{8}{|l|}{ (e) Certification in OSHA } \\
\hline 13. & $\begin{array}{l}\text { Construction firms/contractors certified in OSHA } \\
\text { tend to have good record in road performance }\end{array}$ & $\begin{array}{c}71 \\
(46.4 \%)\end{array}$ & $\begin{array}{c}49 \\
(32.0 \%)\end{array}$ & $\begin{array}{c}31 \\
(20.3 \%)\end{array}$ & $\begin{array}{c}2 \\
(1.3 \%)\end{array}$ & $\begin{array}{c}0 \\
(0.0 \%)\end{array}$ & 4.22 & 0.860 \\
\hline 14. & $\begin{array}{l}\text { Certification in OSHA is a must to ensure road } \\
\text { performance in construction is adhered to }\end{array}$ & $\begin{array}{c}24 \\
(15.7 \%)\end{array}$ & $\begin{array}{c}24 \\
(15.7 \%)\end{array}$ & $\begin{array}{c}56 \\
(36.6 \%)\end{array}$ & $\begin{array}{c}12 \\
(7.8 \%)\end{array}$ & $\begin{array}{c}37 \\
(24.2 \%)\end{array}$ & 3.07 & 1.159 \\
\hline & Composite mean and standard deviation & & & & & & 3.38 & 0.544 \\
\hline
\end{tabular}


The means of 14 items used to generate data on contractors' safety record were summed up and used to compute the composite mean and standard deviation that resulted to 3.38 and 0.544 respectively (Table 5). The statements with lower mean compared to the composite mean were deemed negative and thus influenced contractors' record negatively.

From Table 5, it is apparent that contractors lack safety management policy and that safety is not taken into account for future road performance (Statements 1 and 3). This implies that contractors might be concentrating more on completion of road projects without keen interest to provide long term safety to road users. From statement six, it is also evident that most of the construction firms seem not to have insurance policy. Interestingly, the level or the extent to which contractors comply to safety administration is not clear; thus not able to fully comply with safety requirements (Statements 7 and 8). This is further supported by statement nine that indicates that the environment, within which the contractors operate, does not fully support or appraise compliance to safety procedures. Finally, statement 14, the respondents indicated that a contractor who is certified in OSHA does not need that to guarantee road performance.

Results of interviews with 82 road construction engineers indicated that contractors' safety record influenced largely the performance of road construction infrastructural projects. The interview question posed was that, "In what ways do you think contractors" safety record is likely to influence the performance of road?' The results of the interviews were, therefore, consistent with the quantitative data. The following are key responses obtained from the road construction engineers:

- A compliant contractor ensures a health and safe construction environment even after project completion;

- Quarry or borrow pits when backfilled after project completion ensures security of the environment;

- A safe and a healthy policy among employees is a continued support even after the project completion;

- A safety record of any contractor that is focused on adhering to safety procedures put in place ensures an anticipated highly performing road that is properly marked, has enough road signs; contractors who peg their work on safety are likely to have roads constructed with clearly marked roads and even the issue of bumps will be addressed in such a way that there would be no reason for frequent accidents happening on the roads,

- If all contractors engaged or contracted to undertake road construction work have a clear policy on how to incorporate safety, then performance in terms of safety of pedestrians and even the motorists will be assured.

Results of interviews with 71 public service vehicle (PSVs) drivers indicated contractors' health and safety record influenced largely the performance of road construction infrastructural projects. The results of the interviews were, therefore, consistent with the quantitative data. The following are key responses obtained from the PSVs drivers: 
- A contractor with a clean record of observing safety procedures in his or her previous work will definitely work towards repeating the same in the current assignment;

- Contracts that observe the previous work of a contractor with a keen interest to safety record will tend to produce roads that are performing good in terms of less accidents reported;

- Safety record should also look at the policy put in place by the contractor or the construction firm because this will provide the proof that the contract being awarded will produce good results in terms of a road that is well performing even after its completion;

\subsubsection{Correlation Analysis of Contractors' Safety Record and Performance of Road Construction Infrastructural Projects}

The correlation matrix (Table 6) shows that at 0.05 level of significance, there was statistically significant correlation between contractor's safety record and performance of road construction infrastructural projects ( $\mathrm{p}$-value $<0.05$ ).

The correlation was strong since it had a coefficient of 0.657 . This is an indication that performance of roads could be influenced by contractors' safety road.

\subsubsection{Regression Analysis of Contractors' Safety Record and Performance of Road Construction Infrastructural Projects}

The objective was to examine how contractors' safety record influences performance of road construction infrastructural projects in Nairobi County, Kenya. The dependent variable was performance of road construction infrastructural projects.

The independent variable was contractor's safety record, operationalized by the indicators: safety policy management system; insurance policy; compliance behavior; adequacy of standards in addressing safety outcome; and certification in OSHA.

Test of Hypothesis

The following hypothesis was tested using linear regression model to meet the requirements of the study objective:

Table 6. Correlation matrix for contractors' safety record and performance of road construction infrastructural projects.

\begin{tabular}{cccc}
\hline \multicolumn{2}{c}{ Variable } & $\begin{array}{c}\text { Performance of Road } \\
\text { Construction Projects }\end{array}$ & $\begin{array}{c}\text { Contractor's Safety } \\
\text { Record }\end{array}$ \\
\hline $\begin{array}{c}\text { Performance of Road } \\
\text { Construction Projects }\end{array}$ & Pearson Correlation & 1 & $0.657^{* *}$ \\
\hline Sig. (2-tailed) & 153 & 0.000 \\
Contractor's & Pearson Correlation & $0.657^{* *}$ & 153 \\
\hline Safety Record & Sig. (2-tailed) & 0.000 & 1 \\
& $\mathrm{n}$ & 153 & 153 \\
\hline
\end{tabular}

**. Correlation is significant at the 0.05 level (2-tailed). 
$\mathrm{H}_{0}$ : Contractors safety record does not significantly influence the performance of road construction infrastructural projects in Nairobi County, Kenya.

$\mathrm{H}_{1}$ : Contractors safety record significantly influence the performance of road construction infrastructural projects in Nairobi County, Kenya.

The null hypothesis was tested using the below linear regression model:

$$
y=a+b_{4} X_{4}+e
$$

where:

$y$-Performance of road construction infrastructural projects

$X_{4}$-Contractors' safety record

$B_{4}$-Regression coefficient

a-Regression constant

e-Error term

The results are shown in Tables 7-9.

It was important to establish the goodness of fit of the regression model. The ANOVA (Table 7) established that the model's f-significance value of $\mathrm{p}=0.000$ was less than 0.05 ( $\mathrm{p}=0.00<0.05)$. The calculated $\mathrm{F}(114.556)$ was significantly larger than the critical value of $F=3.904$. The implication of this result is that the model was considered significant.

Table 7. ANOVA for contractors' safety record and performance of road construction infrastructural projects.

\begin{tabular}{ccccccc}
\hline \multicolumn{7}{c}{ ANOVA $^{\mathrm{a}}$} \\
\hline Model & Sum of Squares & df & Mean Square & F & Sig. \\
\hline & Regression & 5.791 & 1 & 5.791 & 114.558 & $0.000^{\mathrm{b}}$ \\
1 & Residual & 7.633 & 151 & 0.051 & & \\
& Total & 13.424 & 152 & & &
\end{tabular}

a. Dependent variable: Performance of road; b. Predictors: (Constant), Contractors' safety record

Table 8. Model summary for contractors' safety record and performance of road construction infrastructural projects.

\begin{tabular}{ccccc}
\hline Model & $\mathbf{R}$ & R Square & Adjusted R Square & Std. Error of the Estimate \\
\hline 1 & $0.657^{\mathrm{a}}$ & 0.431 & 0.428 & 0.22484
\end{tabular}

a. Predictors: (Constant), Contractors' safety record.

Table 9. Model coefficients for contractors' safety record and performance of road construction infrastructural projects.

\begin{tabular}{|c|c|c|c|c|c|}
\hline \multirow{2}{*}{ Model } & \multicolumn{2}{|c|}{$\begin{array}{l}\text { Unstandardized } \\
\text { Coefficients }\end{array}$} & \multirow{2}{*}{$\begin{array}{c}\begin{array}{c}\text { Standardized } \\
\text { Coefficients }\end{array} \\
\text { Beta }\end{array}$} & \multirow[t]{2}{*}{$\mathrm{t}$} & \multirow{2}{*}{ Sig. } \\
\hline & B & Std. Error & & & \\
\hline (Constant) & 2.145 & 0.115 & & 18.692 & 0.000 \\
\hline Contractors' Safety Record & 0.359 & 0.034 & 0.657 & 10.703 & 0.000 \\
\hline
\end{tabular}

a. Dependent variable: Performance of road construction infrastructural projects; Model: $\{\mathrm{B}=0.359, \mathrm{t}=$ $10.703, \mathrm{~F}(1,151)=114.558, \mathrm{p}=0.000<0.05\}$. 
The degree and nature of correlation between contractors' safety record and performance road construction infrastructural projects was determined by the "R" which resulted to 0.657 (Table 8). This shows that contractors' safety record has strong or big influence to road performance in Nairobi County. Arising from R-squared is 0.431 which means that $43.1 \%$ variation is explained by contractors' safety record. On the other hand, it also meant that there could be other factors accounting to $56.9 \%$ that would explain variations in performance of road construction infrastructural projects but are not covered in this model.

The model coefficient results (Table 9) indicate that contractors' safety record had statistically significant influence on performance of road construction infrastructural projects $\{\mathrm{B}=0.359, \mathrm{t}=10.703, \mathrm{~F}(1,151)=114.558, \mathrm{p}=0.000<0.05\}$. The beta (B) coefficient for contractors' safety record is 0.359 . The beta value implies that a unit increase in performance of road construction infrastructural projects corresponds to $35.9 \%$ increase in contractors' safety record.

Using the statistical findings, the regression model can be substituted as follows:

$$
y=2.145+0.359 X_{4}
$$

where:

$$
y \text {-Performance of road construction infrastructural projects }
$$

$X_{4}$-Contractors' safety record

From Table 9, for the predictor variable contractors' safety record, the probability of the $t$ statistic (10.703) for the b coefficient is $0.000<0.001$ which is less than the level of significance 0.05 . The results suggest that the null hypothesis was rejected that the slope associated with contractors' safety record is equal to zero $(b=0)$. Furthermore, the $b$ coefficient associated with financial ability of the contractor (0.359) is positive, which is an indication that a direct relationship exists. These findings warranted rejection of the null hypothesis $\left(\mathrm{H}_{0}\right)$ which stated that contractors' safety record does not significantly influence performance of road construction infrastructural projects. Hence, we conclude that contractors' safety record influence performance of road construction infrastructural projects.

The findings of the study indicate that contractors' safety record influences performance of the road. The findings therefore support a study by Kartam and Bouz who discovered that weak systems for accident recording and reporting were a conduit for hiding the pervasive safety gaps [16]. The culture of keenness to safety issues has also been said to critically set the attitude and the significance of organizational safety.

The current findings from descriptive analysis of the outcome variable, performance of road construction infrastructural projects, on road safety as a dimension, found that although reported cases of accidents have reduced (line item mean of 3.78 against 3.35 the composite mean), bumps are not provided in the right designated places (line item mean of 3.13 against a composite mean of 3.35), pedestrians' walkways are not adequately provided (line item mean of 2.99 
against a composite mean of 3.35), foot bridges are not sufficiently provided (line item mean of 1.98 against a composite mean of 3.35) and bus stops are not well placed in the right designated areas (line item mean of 2.22 against a composite mean of 3.35). The findings support De Saram and Tang who examined the non-material accident costs, including pain and suffering, and loss of quality of life and reported that the said costs comprised approximately thirty percent of direct costs of accident [34]. There is critical need to re-focus our energy in improving road safety to enhance performance of road construction infrastructural projects.

This finally confirms the Domino theory of accident causation borrowed in the current study and as advanced H. W. Heinrich in 1931. The first three of the five sequential antecedents from the Domino theory explains the scenario here [23]. In the first antecedent, the social ecosystem and ancestry which are among the process of knowledge acquisition at workplaces encompassing culture, values, and attitudes; lacking of skills as well as technology for task performance, poor ecosystem and social conditions leads to human fault. The second antecedent shows that carelessness which mainly is a description of adverse personal attributes, acquired or otherwise. Such carelessness are antecedent to poor work conditions. And from the third antecedent, hazardous human acts, with risky conditions encompassing the faults as well as technical failures leading to accidents (Such as poor or lack of installation of foot bridges and clear marking of the road). The theory has overly been used during assessment of a contractor for award of the tender to undertake construction works without factoring in the aspect of performance during post-delivery of the project hence the need for its adoption in this regard.

The current study has established that contractors' compliance behavior is not good. The study has also revealed that compliance to safety administration is not clear, contractors do not fully comply to safety requirements and the environment in which contractors operate do not care to appraise compliance to safety issues or procedures. The findings therefore point out the need for basic safety investment in construction industry as found by Feng [9]. Further, the findings set a call for disaster preparation, planning, use of protective equipment (in this case, accident prevention mechanisms such as foot bridges) and management engagement as found by Jannadi and Bu-Khamsin while studying on safety determinants in the Saudi Arabian context [22].

The current study found that most of the contractors do not have safety policy management system (a lower line item mean of 3.33 compared to the composite mean of 3.38). These results are in support of Diugwu, Baba and Egila study whose findings indicated that $55.9 \%$ of construction firms have no safety and health policies in their organizations [19]. This implies that there is need to strengthen the OSHA aspects within construction industry to avoid the massive accidents occurring in the post-delivery stage of the road projects, upon completion.

The alternate hypothesis was, thus, supported by data since contractor's safety 
record was found to significantly influence performance of road construction infrastructural projects. In relation to the foregoing comparable studies, the current study has adduced empirical evidence in support of the earlier findings.

\section{Conclusion}

The study objective was to examine how contractors' safety record influences performance of road construction infrastructural projects in Nairobi County, Kenya. The null hypothesis that was tested in this regard was that contractors' safety record does not significantly influence performance of road construction infrastructural projects. The results were: $\mathrm{R}=0.657, \mathrm{R}^{2}=0.431, \mathrm{~B}=0.359, \mathrm{t}=$ $10.703, \mathrm{~F}(1,151)=114.558, \mathrm{p}=0.000<0.05$. The null hypothesis was rejected based on the results, and it was concluded that contractors' safety record significantly influences performance of road construction infrastructural projects. The results showed that contractors' safety record explained $43.1 \%$ of performance of road construction infrastructural projects. Aspects of contractors' safety record that should be observed are thus listed as follows: safety policy management system, insurance policy, compliance behavior, adequacy of standards in addressing safety outcomes and finally certification in OSHA.

\section{Recommendations}

Evaluation of contractors prior to being awarded a tender is very critical to establish their ability to do the job. The findings show that contractors' safety record explains to a total of $43.1 \%$ of performance of road construction infrastructural. This indicates that contractors' safety record should be considered in the criteria system of contractor selection to assist in improving road performance. The past of the contractor's adherence to safety aspects such as footbridges, pedestrians' walkways, proper use of road signage need to be checked prior to awarding road construction tenders so as to eliminate undeserving contractors.

A similar study may be carried out on building construction using the same predictor and outcome variable. Since this study focused on Nairobi County, generalization of the findings to other regions or counties may not be feasible and therefore future studies need to be based in other geographical areas within Kenya. Future studies should find out the contribution of contractors' safety ability when combined with other evaluation criteria such as management ability, technical ability, and contractors' safety record.

\section{Conflicts of Interest}

The authors declare no conflicts of interest regarding the publication of this paper.

\section{References}

[1] Wegman, F. (2017) The Future of Road Safety: A Worldwide Perspective. 
IATSS Research, 40, 66-71. https://doi.org/10.1016/j.iatssr.2016.05.003

[2] United Nations (2018) Road Safety Performance Review Uganda. https://www.unece.org/fileadmin/DAM/road Safety/Documents/RSPR Uganda Fe bruary 2018/Uganda Road Safety Performance Review Report web version.pdf

[3] Australian Government (2012) A Systematic Review of the Effectiveness of Safety Management Systems Commonwealth of Australia. https://www.atsb.gov.au/media/4053559/xr2011002 final.pdf

[4] IFC (2017) Managing Contractors' Environmental and Social Performance. World Bank International Finance Corporation, Washington DC.

[5] Emeasoba, U.R. and Ogbuefi, J.U. (2013) Sustainable Socio-Economic Development in Nigeria: A Case for Road Infrastructure Maintenance. Journal of Environment and Earth Science, 3, 129-137.

[6] Ogendi, J., Odero, W., Mitullah, W. and Khayesi, M. (2013) Pattern of Pedestrian Injuries in the City of Nairobi: Implications for Urban Safety Planning. Journal of Urban Health, 90, 849-856. https://doi.org/10.1007/s11524-013-9789-8

[7] Griffin, M.A. and Neal, A. (2000) Perceptions of Safety at Work: A Framework for Linking Safety Climate to Safety Performance, Knowledge, and Motivation. Journal of Occupational Health Psychology, 5, 347-358. https://doi.org/10.1037//1076-8998.5.3.347

[8] Manyara, C.G. (2013) Combating Road Traffic in Kenya: A Challenge for Emerging Economy. KESSA Proceedings 2013.

[9] Feng, Y. (2013) Effects of Safety Investments on Safety Performance of Building Projects. Safety Science, 59, 28-45. https://doi.org/10.1016/j.ssci.2013.04.004

[10] Kahongeh, J. (2019) The Death Trap That Is Nairobi's Outer Ring Road. Daily Nation, Friday November 15, 2019.

https://www.nation.co.ke/news/-death-trap-Nairobi-Outer-Ring-Road/1056-534996 4-2p89w9z/index.html

[11] Nairobi City County Government (NCCG) (2015) Non Motorized Transport Policy: Towards NMT as the Mode of Choice. Nairobi City County Government, Nairobi.

https://www.kara.or.ke/Nairobi\%20City\%20County\%20Non\%20Motorized\%20Tra nsport\%20Policy.pdf

[12] Kinyanjui, M. (2018) Weed out Incompetent Contractors, PS Korir Tells Sonko on Poor Roads.

https://www.the-star.co.ke/news/2018/05/10/weed-out-incompetent-contractors-ps -korir-tells-sonko-on-poor-roads c1756529

[13] Hall, M. and Holt, R. (2003) Developing a Culture of Performance Learning in UK Public Sector Project Management. Public Performance and Management Review, 26, 263-275. https://www.tandfonline.com/doi/abs/10.1177/1530957602250230 https://doi.org/10.1177/1530957602250230

[14] Heinrich, H.W., Peterson, D. and Roos, N. (1980) Industrial Accident Prevention. 5th Edition, McGraw Hill, New York.

[15] Koehn, E., Kothari, R.K. and Pan, C.-S. (1995) Safety in Developing Countries: Professional and Bureaucratic Problems. Journal of Construction Engineering Management, 121, 261-265. https://doi.org/10.1061/(ASCE)0733-9364(1995)121:3(261)

[16] Kartam, N.A. and Bouz, R.G. (1998) Fatalities and Injuries in the Kuwaiti Construction Industry. Accident, Analysis and Prevention, 30, 805-814.

https://doi.org/10.1016/S0001-4575(98)00033-5 
[17] O'Toole, M. (2002) The Relationship between Employees' Perceptions of Safety and Organizational Culture. Journal of Safety Research, 33, 231-243.

http://158.132.155.107/posh97/private/culture/relationship-Toole.pdf https://doi.org/10.1016/S0022-4375(02)00014-2

[18] Weil, D. (2001) Assessing OSHA Performance: New Evidence from the Construction Industry. Journal of Policy Analysis and Management, 20, 651-674.

http://www.fissuredworkplace.net/assets/Weil.AssessingOSHAConstruction.JPAM. 2001.pdf

https://doi.org/10.1002/pam.1022

[19] Diugwu, I.A., Baba, D.L. and Egila, A.E. (2012) Effective Regulation and Level of Awareness: An Expose of the Nigerian's Construction Industry. Open Journal of Safety and Technology, 2, 140-146. https://doi.org/10.4236/ojsst.2012.24018

[20] Ngacho, C. and Das, D. (2014) A Performance Evaluation Framework of Development Projects: An Empirical Study of Constituency Development Fund (CDF) Construction Projects in Kenya. International Journal of Project Management, 32, 492 507. https://doi.org/10.1016/j.ijproman.2013.07.005

[21] Alzahrani, J.I. and Emsley, M.W. (2013) The Impact of Contractors' Attributes on Construction Project Success: A Post Construction Evaluation. International Journal of Project Management, 31, 313-322. https://doi.org/10.1016/j.ijproman.2012.06.006

[22] Jannadi, O. and Bu-Khamsin, M. (2002) Safety Factors Considered by Industrial contractors in Saudi Arabia. Building and Environment, 37, 539-547. https://doi.org/10.1016/S0360-1323(01)00056-7

[23] Hosseinian, S.S. and Torghabeh, Z.J. (2012) Major Theories of Construction Accident Causation Models: A Literature Review. International Journal of Advances in Engineering and Technology, 4, 53-66.

[24] Sabet, P.G.P., Aadal, H., Jamshidi, M.H.M. and Rad, K.G. (2013) Application of Domino Theory to Justify and Prevent Accident Occurrence in Construction Sites. Journal of Mechanical and Civil Engineering (IOSR-JMCE), 6, 72-76. http://www.iosrjournals.org/iosr-jmce/papers/vol6-issue2/I0627276.pdf https://doi.org/10.9790/1684-0627276

[25] Mahat, N.A.A., Ismail, F. and Alwee, S.N.A.S. (2015) Integration of Quality Management and Construction Accident Causation: Development of Accident Causation Theories. Australian Journal of Accident Basic and Applied Sciences, 9, 123 129.

http://www.ajbasweb.com/old/ajbas/2015/Special\%20IPN\%20Langkawi\%20(June)/1 23-129.pdf

[26] Johnson, R.B. and Onwuegbuzie, A.J. (2004) Mixed Methods Research: A Research Paradigm Whose Time Has Come. Educational Researcher, 33, 14-26.

https://doi.org/10.3102/0013189X033007014

[27] Greenfield, R. and Morgan, M.J.W. (2014) Management of Health and Safety Performance of Facilities Management. British Institute of Facilities Management, Hertfordshire.

[28] Bernard, H.R. (2000) Social Research Methods: Qualitative and Quantitative Approaches. Sage Publications, Thousand Oaks.

[29] Cooper, D.R. and Schindler, P.S. (2006) Business Research Methods. 9th Edition, McGraw-Hill, New York.

[30] Enshassi, A., Mohamed, S. and Abushaban, S. (2009) Factors Affecting the Performance of Construction Projects in the Gaza Strip. Journal of Civil Engineering and 
Management, 15, 269-280. https://doi.org/10.3846/1392-3730.2009.15.269-280

[31] Nyangwara, P.O. and Datche, E. (2015) Factors Affecting the Performance of Construction Projects: A Survey of Construction Projects in the Coastal Region of Kenya. International Journal of Scientific and Research Publications, 5, 1-43. http://www.ijsrp.org/research-paper-1015/ijsrp-p46121.pdf

[32] Saunders, M., Lewis, P. and Thornhill, A. (2009) Research Methods for Business Students. Pearson, New York.

[33] Mugenda, A.G. and Mugenda, O. (2003) Research Methods: Quantitative and Qualitative Approach. ACTS Press, Nairobi.

[34] De Saram, D.D. and Tang, S.L. (2005) Pain and Suffering Costs of Persons in Construction Accidents: Hong Kong Experience. Construction Management Economics, 23, 645-658. https://doi.org/10.1080/01446190500039739 